\title{
A revolução russa e o nascimento de um marxismo latino-americano: a influência bolchevique no pensamento de José Carlos Mariátegui
}

Erick Kayser $^{1}$

Resumo: A Revolução Russa de outubro de 1917 gerou a sinergia de uma ruptura na ordem vigente que rapidamente ultrapassou as suas fronteiras natais. A América Latina sentiria seus efeitos traduzidos em um crescimento do comunismo e das ideias marxistas na região. Buscar-se-á demonstrar neste artigo a hipótese que a Revolução Russa não apenas contribuiu para a difusão do marxismo na região, mas também, mesmo que inadvertidamente, propiciou o surgimento de um marxismo originalmente latino-americano. Influenciado pela vitória dos bolcheviques, o pensamento marxista teria naquele momento seus primeiros esforços mais significativos de adaptação ao contexto local. Para explorar tal questão, destacamos o pensamento do peruano José Carlos Mariátegui. Buscando sua referência teórica no leninismo, o exame do pensamento de Mariátegui nos permitirá vislumbrar os novos caminhos para o marxismo possibilitados pela "abertura na história" da revolução russa.

Palavras-chave: Revolução Russa; Marxismo; José Carlos Mariátegui

\section{The Russian revolution and the birth of a Latin American Marxism: the Bolshevik influence in the thought of José Carlos Mariátegui}

\begin{abstract}
The Russian Revolution of October 1917 generated the synergy of a rupture in the prevailing order that quickly transcended its natal boundaries. Latin America would feel its effects translated into a growth of communism and Marxist ideas in the region. It will be tried to demonstrate in this article that the Russian Revolution not only contributed to the spread of Marxism in the region, but also, even if inadvertently, gave rise to an originally Latin American Marxism. Influenced by the victory of the Bolsheviks, Marxist thought would now

1 Doutorando em História na Universidade Federal do Rio Grande do Sul (UFRGS), Brasil. Parte da pesquisa realizada para o artigo foi feita durante a investigação para a dissertação defendida em 2017 (Marxismo, Eurocentrismo e América Latina: uma análise a partir da obra de José Carlos Mariátegui.). Esta pesquisa teve financiamento da CAPES. E-mail: erickdasilva@gmail.com
\end{abstract}

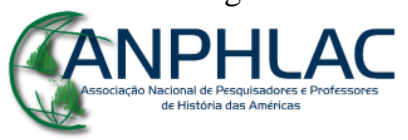

Revista Eletrônica da ANPHLAC, ISSN 1679-1061, №. 25, p. 87-115, Jul./Dez., 2018.

http://revista.anphlac.org.br 
have its first significant efforts to adapt to the local context. To explore this issue, we highlight the thought of the Peruvian José Carlos Mariátegui. Seeking its theoretical reference in Leninism, the examination of Mariátegui's thinking will allow us to glimpse the new paths to Marxism made possible by the "openness in history" of the Russian revolution.

Keywords: Russian revolution; Marxism; José Carlos Mariátegui

Artigo recebido em: 06/05/2018

Artigo aprovado em: 09/12/2018

A recente passagem do centenário da Revolução Russa de 1917 é uma rica oportunidade que nos convida a refletir sobre seus impactos na América Latina. O ineditismo da experiência revolucionária liderada pelos bolcheviques gerou a sinergia de uma ruptura na ordem vigente que rapidamente ultrapassou as suas fronteiras natais. Prova disto é que o comunismo rapidamente passaria a ganhar mais adeptos e simpatizantes políticos na região. Se observarmos que anteriormente o marxismo possuía uma frágil penetração no conjunto da América Latina, após 1917 as ideias comunistas ganhariam um notável impulso.

Poucos anos após a revolução soviética, boa parte dos países da região passariam já a contar com partidos organizados em torno dos ideais comunistas e se autoproclamando marxistas-leninistas. Assim, não é exagero afirmar que a revolução russa foi um divisor de águas na história das ideias marxistas na América Latina. O interesse pelas ideias dos principais líderes revolucionários russos (Lenin, Trotsky, Bukharin, Stálin, Zinoviev, entre outros) foi considerável e, em certa medida, crescente, mas também propiciou um interesse nas obras do chamado marxismo clássico e seus fundadores, os alemães Karl Marx e Friedrich Engels.

Os Partidos Comunistas fundados naquele período, de forma quase invariável, buscariam se espelhar na experiência que havia se mostrado exitosa na Rússia. Se por um lado o comunismo, como expressão política, seria diretamente inspirado pelo modelo organizativo soviético, por outro lado, no período que se inicia em 1918 e adentrará até fins da década seguinte, gestaram-se no âmbito teórico formas originais de interpretação do marxismo. A hipótese que se buscará demonstrar neste artigo é que a revolução russa não apenas contribuiu para a difusão do marxismo na região, mas também, mesmo que inadvertidamente, propiciou

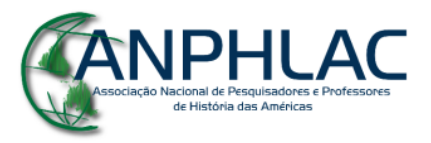

Revista Eletrônica da ANPHLAC, ISSN 1679-1061, №. 25, p. 87-115, Jul./Dez., 2018.

http://revista.anphlac.org.br 
o surgimento de uma inflexão no marxismo originalmente latino-americana. Influenciado pela Revolução Russa, o pensamento marxista teria nesse momento alguns de seus primeiros esforços mais significativos de adaptação ao contexto local. Para explorar tal questão, destacamos o pensamento do peruano José Carlos Mariátegui, cuja obra é uma referência por sua originalidade e pioneirismo.

Cabe aqui destacar a especificidade da noção de marxismo latino-americano. No percurso de uma história das ideias, indivíduos identificados de alguma forma com os escritos de Karl Marx, em fins do século XIX, já se encontravam em número significativo, espalhados pela América do Sul, Central e Caribe. No entanto, tratavam-se, a grosso modo, de marxistas na América Latina que muitas vezes reproduziam, de forma quase mecânica, algumas noções do marxismo europeu sem o devido e necessário esforço de contextualização e atualização. Se em parte essa dinâmica se mantém após 1917, não foi a única via de desenvolvimento do marxismo, como um olhar mais apressado poderia concluir. $\mathrm{Na}$ esteira da ascensão do marxismo-leninismo, gestaram-se formas de elaboração teórica nas quais, utilizando-se do instrumental teórico do marxismo, buscava-se dialeticamente analisar a América Latina fomentando alguns aportes teóricos originais significativos. Assim, avançava-se de uma prática anterior na qual a divulgação e reprodução do marxismo produzido na Europa eram a forma privilegiada na região para uma tentativa de elaboração original. Nesse esforço para tornar o marxismo genuinamente latino-americano, levaria-se em conta premissas tais como o passado colonial, as especificidades da estrutura econômica local e a dependência dos países da região ao julgo imperialista, realidade significativamente diversa da europeia.

A seguir, buscar-se-á apontar alguns dos impactos imediatos e subsequentes da chegada do leninismo na América Latina, destacando-se desse contexto a figura do intelectual peruano José Carlos Mariátegui. O exame do pensamento mariateguiano nos permitirá vislumbrar os novos caminhos para o marxismo possibilitados pela "abertura na história" da revolução russa. Na conclusão, esboçar-se-á uma síntese possível de tal itinerário teórico de Mariátegui, no qual, embora com a predominância de um esforço de fidelidade, as novas ideias chegadas da Rússia foram diversas vezes reinterpretadas, gerando novas sínteses, cujas potencialidades e limites inerentes (ou contingentes) buscarão ser delineados.

\section{GANPHLAC}




\section{Revolução russa e o nascimento do marxismo latino-americano}

A história das primeiras manifestações socialistas latino-americanas, em sua fase prémarxista, conforme Carlos M. Rama (1980, p. 97) foi iniciada após 1830, a partir de três vias: intelectuais da primeira geração independentista, nascidos ao redor de 1810, que recorreriam especialmente a Paris em busca de novas ideias utópicas; intelectuais europeus de ideias socialistas, que, por razões políticas, se refugiavam nos países latino-americanos, e, por fim, a partir de trabalhadores europeus com alguma experiência sindical que se estabeleciam como imigrantes. Os primeiros registros das ideias marxistas no continente latino-americano datam já em paralelo ao seu surgimento na Europa, na sequência das revoluções europeias de 1848, de forma incipiente e com algumas barreiras para sua difusão, que se mostraram quase intransponíveis.

O escasso acesso às obras de Marx e Engels era um complicador adicional para sua difusão no continente, situação que persistiria por longos anos. O Manifesto Comunista, por exemplo, tem sua primeira tradução conhecida em espanhol publicada em 1872; já a primeira tradução brasileira, de autoria do alagoano Octávio Brandão, seria lançada em $1923^{2}$. Ainda que o nome de Marx fosse razoavelmente conhecido em círculos intelectualizados, o desencontro com suas ideias era flagrante. Um exemplo notável é o do cubano José Martí e sua reação frente ao marxismo. Martí teve acesso às obras de Marx e nutria respeito pelo pensador alemão, mas ele se oporia à noção de luta de classes, um dos motivos que o afastaria das ideias marxianas. Ele postula uma saída harmoniosa (e espiritualizada) para as vicissitudes humanas ${ }^{3}$.

As reservas e o distanciamento de José Martí ao marxismo não seriam caso raro na América Latina. As diferentes tradições espiritualistas e/ou idealistas, muito difundidas na região, dificultariam naquele momento a adesão de muitos filósofos e intelectuais ao dito

2 Sobre essa tradução, "O texto foi publicado pelo jornal Voz Cosmopolita, partir do número 38 (correspondente a $1^{\circ}$ de dezembro de 1923). O jornal era, como se lia na primeira página, o 'órgão dos empregados em hotéis, restaurantes, cafés, bares e anexos'. Em seguida apareceu em forma de livro, impresso em Porto Alegre (1924), com a indicação: 'traduzido da edição francesa de Laura Lafargue (filha de Marx), revista por Engels'. Outra tradução seria feita em 1931, por um tradutor anônimo, e lançada em São Paulo pela editora Unitas" (KONDER, 1998, p.48).

3 Contra a solução dura de Marx, Martí propunha uma solução "suave". Ainda que partilhasse e reconhecesse os diagnósticos marxianos, julgava que ele "foi precipitado e tateava no escuro, sem ver que não nascem viáveis, nem do seio de um povo na história e nem do seio de uma mulher em casa provêm filhos aptos a sobreviver se não forem fruto de um desenvolvimento natural e diligente" (MARTÍ, [1883], 2010, p.65).

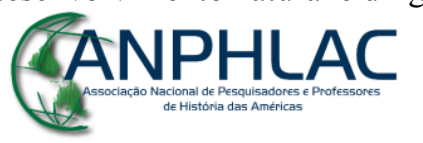

Revista Eletrônica da ANPHLAC, ISSN 1679-1061, №. 25, p. 87-115, Jul./Dez., 2018.

http://revista.anphlac.org.br 
"materialismo de Marx"4. Mas estes não foram os únicos fatores a corroborar para as dificuldades iniciais do marxismo na América Latina. Tal "desencontro" merece também ser observado por outro ângulo, examinando a indiscutível escassa atenção que Marx e Engels prestaram à América Latina, situação que pode se definir como uma "soberana indiferença" (ARICÓ, 2009, p.82). Mesmo raramente ocupando um lugar central nas análises marxianas, os poucos escritos com referência à América Latina dos fundadores do marxismo revelam uma postura pouco favorável ao continente ${ }^{5}$. Essa percepção de ambos se deriva de uma matriz hegeliana da filosofia da história, só superada, especialmente por Marx, em seus escritos maduros ${ }^{6}$.

Na Europa, desde seu nascimento o marxismo seria marcado pela busca de uma organização política internacionalista, tendo seu ponto alto nas chamadas Internacionais, primeiro a partir da Associação Internacional dos Trabalhadores (AIT), fundada em 1864 e dissolvida em 1876, que contou com a presença de Marx e Engels em sua liderança. Em 1889, contando ainda com a participação de Engels, foi fundada a chamada Segunda Internacional ${ }^{7}$, liderada pelo partido social-democrata alemão, organização a qual, assim como já havia ocorrido com a AIT, apesar das pretensões internacionalistas, seria basicamente europeia. À exceção da Argentina (que veremos a seguir), a II ${ }^{\circ}$ Internacional teria pouca presença na América Latina e durante a crise política aberta com a eclosão da Primeira Guerra Mundial, divergências de teor chauvinista entre os partidos europeus implodiriam a Internacional

4 Um exemplo seria o filósofo brasileiro Raimundo Farias Brito, que publicaria em Fortaleza, em 1899, seu livro A Filosofia Moderna, onde polemizaria com as ideias de Marx, acusando-o de defender um socialismo meramente materialista, o que degradaria os esforços humanos por uma melhor organização social e espiritual, reduzindo a luta humana a uma mera questão de subsistência, abandonando a importância das ideias (FORNET-BETANCOURT, 1995, p.35).

5 O exemplo mais conhecido nos debates contemporâneos é o artigo de Marx sobre Simón Bolívar, publicado em 1858, no terceiro tomo da The New American Cyclopaedia, no qual a abordagem crítica e desfavorável do personagem, retratado como um tipo de ditador bonapartista, escaparia da "imparcialidade" que um texto enciclopédico exigiria, fato que o próprio Marx reconheceu em carta a Engels de 14 de fevereiro de 1858, no qual comenta que abandonou o tom enciclopédico porque "Teria sido demais querer apresentar, como Napoleão I, o canalha mais covarde, brutal e miserável. Bolívar é o verdadeiro Soulouque” (MARX [1858] 1972, p.94). Essa comparação é reveladora, pois precisamente ao nome do imperador haitiano usado como comparação com Bolívar, é o mesmo que tanto Marx como Engels usam para ridiculizar a Luís Napoleão III.

6 Sobre esse aspecto na evolução no pensamento de Marx, ver BIANCHI, 2010.

7 Também conhecida como Internacional Socialista.

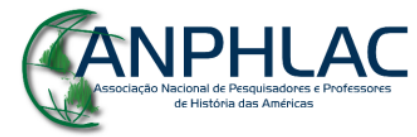

Revista Eletrônica da ANPHLAC, ISSN 1679-1061, №. 25, p. 87-115, Jul./Dez., 2018.

http://revista.anphlac.org.br 
Socialista, tendo suas atividades encerradas em 1914. Alguns anos depois, em 1919, liderada pelos revolucionários russos, seria fundada a III $^{\circ}$ Internacional $^{8}$.

Se nos primeiros anos do século XX, de uma maneira geral, as ideias marxistas tinham uma presença ainda frágil do ponto de vista político e social na América Latina, na região do Prata na América do Sul a situação era um pouco diferente. Tendo um contexto regional de ampla imigração europeia, industrialização precoce e alto grau de urbanização (em comparação ao restante do continente), tais fatores corroboraram decisivamente (mas não de forma exclusiva) para certo pioneirismo local no surgimento de organizações políticas de cunho marxista. Um exemplo notável foi o Partido Socialista Argentino (PSA), fundado em 1896, que obteria, relativamente rápido, importantes vitórias políticas. Ao contrário de outras organizações políticas na região, desde sua origem o PSA estabeleceria relações diretas com a Segunda Internacional ${ }^{9}$. Tendo Juan B. Justo como principal expoente, o PSA contribuiria para a organização política dos socialistas para além das fronteiras argentinas ${ }^{10}$.

O processo de industrialização que se inicia a partir do final do século XIX, de forma fraca, mas ainda sim significativa, em países como Argentina, Brasil e México, vinculado ao setor primário-exportador e subordinado a relações de dependência com as potências imperialistas, daria-se de forma mais ou menos contínua nas décadas seguintes, tendo seu curso parcialmente alterado com a $\mathrm{I}^{\mathrm{o}}$ Guerra Mundial e, de forma mais profunda, com a crise econômica de 1929. Por decorrência da industrialização, as classes trabalhadoras urbanas se expandiram acompanhadas do crescimento dos sindicatos e de sua capacidade de organização política. Os socialistas e, a partir de 1918, os comunistas disputavam a direção política dos trabalhadores organizados com os Anarcossindicalistas e outras correntes políticas, havendo, no entanto, fatores externos ao "chão das fábricas" que impulsionariam as ideias marxistas na América Latina.

O marxismo latino-americano se beneficiará da efervescência do contexto políticosocial que varreu quase todo o continente na década de 1910. A década se inicia com a

8 Cabe destacar que já no contexto do encerramento das atividades da II $^{\circ}$ Internacional, Lenin imediatamente faria um chamado pela criação de uma III ${ }^{\circ}$ Internacional: “A Segunda Internacional está morta, vencida pelo oportunismo. Abaixo o oportunismo e viva a Terceira Internacional...” ([1914] 1984, p.176).

9 Como registra Aricó (2009, p.80), o PSA participaria de "quase todos os congressos internacionais e ocupou um posto permanente nas sessões do Bureau Socialista Internacional desde 1901 até as vésperas da Primeira Guerra Mundial".

10 O PSA atuaria, por exemplo, "estimulando a formação de um partido socialista no Chile (que foi criado em 1897, mas pouco durou) e a transformação de um partido socialista no Uruguai, dirigido pelo ensaísta e professor de direito Emílio Frugoni” (KONDER, 2009, p.87)

\section{GANPHLAC}

Revista Eletrônica da ANPHLAC, ISSN 1679-1061, №. 25, p. 87-115, Jul./Dez., 2018.

http://revista.anphlac.org.br 
Revolução Mexicana, passaria pela crise mundial da guerra europeia e as mobilizações estudantis desencadeadas por toda a região pelo movimento da Reforma Universitária de Córdoba $^{11}$. Mas o catalisador fundamental para a difusão do marxismo na região foi, sem dúvida, a Revolução Russa de Outubro de 1917.

A conturbada conjuntura russa era acompanhada com atenção por muitos latinoamericanos desde a queda do Czar e a instalação do governo provisório em fevereiro de $1917^{12}$. A revolução de outubro provocaria uma mudança qualitativa nessa percepção, já nos primeiros meses após a revolução, campanhas de ataques ao "bolchevismo" e reações em sua defesa já compunham o cenário ${ }^{13}$. O efeito propagador das ideias, mas principalmente do êxito político do partido liderado por Lenin foi significativo. Foi a partir de 1917 que o marxismo na América Latina começou a ter uma organização política inédita. Passaríamos a contar com partidos formalmente organizados em torno do ideário comunista, primeiramente na Argentina em 1918, no México em 1919, no Uruguai em 1920 e no Brasil e Chile em 1922, entre outros ${ }^{14}$. Em comum nessas primeiras experiências foi a busca em seguir o modelo organizativo e as diretrizes políticas inspiradas pelas orientações vindas da Terceira Internacional.

Cumpre registrar que mesmo tendo essas marcas comuns nos anos 1920, tanto a difusão do marxismo quanto a formação de uma cultura marxista na América Latina (em termos teóricos e políticos) não foi um processo homogêneo. A heterogeneidade que o exame daquele período revela carregar consigo a realidade própria de uma região continental cujas formações sociais revelam-se muito diversas, países com um desenvolvimento desigual de suas forças produtivas, estruturas de classe, problemas étnicos e culturais específicos e

11 Foram significativos os impactos políticos advindos das mobilizações estudantis pela Reforma Universitária que se iniciam em 1918 em Córdoba, na Argentina, que, como uma onda, se estenderia de forma temporalmente descontinua por boa parte da região. Primeiro no Peru, depois Chile, mais tarde Cuba, Colômbia, Guatemala e Uruguai. Uma segunda onda posterior à 1930 atinge o Brasil, Paraguai, Bolívia, Equador, Venezuela e México. Para uma análise dos efeitos políticos desse movimento para o marxismo e as esquerdas em geral no continente, ver Portantiero (1978).

12 No geral, a queda do czar Nicolau seria saudada pela grande imprensa latino-americana, afirma o historiador Boris Koval (1980), retratando como o fim de um governo autocrático e a chegada de Kerenski o início de um regime "moderno" e "democrático".

13 Os primeiros reflexos da cruzada antibolchevique podem ser verificados na reação de Mariátegui, que em 9 de abril de 1918, publica no jornal El Tiempo, um texto sob o pseudônimo de Juan Croniquer, com o título Bolchevique, aqui, onde comenta as frequentes censuras que já havia sofrido por ser supostamente bolchevique.

14 Surgem como exceções tardias poucos partidos comunistas fundados após este período: Bolívia,1950; Honduras, 1954 e Nicarágua, 1967. (NETTO, 2012, p.43)

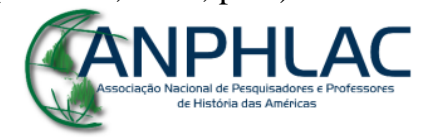

Revista Eletrônica da ANPHLAC, ISSN 1679-1061, №. 25, p. 87-115, Jul./Dez., 2018.

http://revista.anphlac.org.br 
diferentes inserções internacionais. Tal ponderação, no entanto, não interdita a observação desses processos regionalmente compartilhados, mas busca evitar interpretações simplificadoras da expansão das ideais comunistas.

Mesmo com tantos países latino-americanos tendo fundado seus partidos comunistas, durante seus primeiros anos, a Internacional Comunista pouca atenção depositou na América Latina. Em boa medida isso ocorria devido a débil força social dos comunistas latinoamericanos, o que colaborava para que tal distanciamento provocasse um considerável desconhecimento do Komintern sobre a conjuntura da região, provocando toda a sorte de equívocos $^{15}$, situação que se modificaria a partir de 1928, após a realização do VI Congresso da Internacional Comunista, quando passa a ter uma presença mais efetiva do Komintern na região, já sob efeitos do stalinismo. Como desdobramento dessa nova política, realizam-se em 1929 o primeiro Congresso Sindical Latino-americano, em Montevidéu e a primeira Conferência Comunista Latino-americana, em Buenos Aires, assim como se amplia o intercâmbio de comunistas da região com $\operatorname{Moscou}^{16}$. Na década de 1930, a conjuntura europeia de crescimento do fascismo e as questões internas da URSS (inicio dos processos de Moscou) abreviariam o investimento político soviético para região.

Mesmo sofrendo de toda a sorte de adversidades, como dificuldades materiais, disputas com outras forças políticas e até mesmo perseguições por parte dos governos nacionais $^{17}$, os partidos comunistas nascidos após a vitória soviética contribuiriam decisivamente para uma maior difusão e popularização do marxismo. Tomando o exemplo do Brasil, pode-se dimensionar melhor tal aspecto. Se antes de 1922, quando o PCB fora fundado, eram escassas as publicações relacionadas ao pensamento marxista em circulação, após 1924 começariam a publicar as primeiras traduções das obras de V. I. Lênin, e já em 1926, o PCB conseguiu difundir mais de 254 mil exemplares de diferentes folhetos e trabalhos marxistas-leninistas (ZORÍNA, 1952).

15 Um exemplo dessas incompreensões da Internacional com a América Latina é o caso brasileiro, no qual "os dirigentes da Internacional Comunista em Moscou só souberam que aqui se falava português e não espanhol, muitos anos depois do partido comunista brasileiro ter se filiado à Internacional. Havia um grande desconhecimento sobre o país por parte dos comunistas russos e não russos, que fez com que as intervenções da Internacional fossem sempre desastrosas" (GORENDER, 1997, p.144).

16 Para um levantamento mais pormenorizado da presença de lideranças latino-americanas nos espaços políticos da Internacional Comunista (Congressos, Bureaus regionais, Profintern, etc), assim como nas formações nas Escolas de Quadros em Moscou, ver JEIFETS \& JEIFETS (2015).

17 No México, por exemplo, o Partido Comunista seria posto na ilegalidade em 1929.

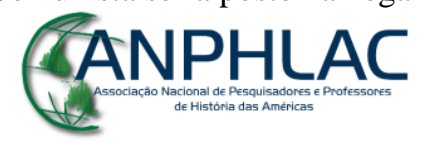

Revista Eletrônica da ANPHLAC, ISSN 1679-1061, №. 25, p. 87-115, Jul./Dez., 2018.

http://revista.anphlac.org.br 
Ao lado das obras dos líderes russos e algumas traduções de clássicos do marxismo, muitos autores latino-americanos publicaram obras de divulgação do marxismo e tentativas de análise das conjunturas nacionais utilizando-se do marxismo, mas nem sempre com sucesso e de forma incipiente ${ }^{18}$. Observando-se de um ponto de vista da análise crítica das ideias desenvolvidas naquele momento, de uma forma geral, o pensamento marxista na América Latina seria caracterizado predominantemente por uma reprodução mais ou menos direta dos princípios irradiados de fora do continente, basicamente da URSS, mas também da Europa. Eram raras elaborações teóricas que fugissem de um certo esquematismo derivado de uma interpretação literal das obras de referência do marxismo-leninismo. Como consequência, a presença do eurocentrismo seria de grande abrangência entre esses marxistas latinoamericano. Em linhas gerais, consistia em transplantar para a América Latina os modelos analíticos da realidade europeia. A influência do eurocentrismo no marxismo, ao analisar o conjunto do continente, expressava-se “[...] na leitura destas sociedades a partir da cosmovisão europeia e seu propósito de transformá-las à imagem e semelhança das sociedades do Norte, que em sucessivos momentos históricos serviram de modelo a ser imitado" (LANDER, 2007, p.223) Dessa forma, conceitos eram adaptados ou enxertados muitas vezes de forma alheia à realidade objetiva: a estrutura agrária era classificada como "feudal", a burguesia local considerada como "progressista", o campesinato seria hostil ao coletivismo socialista etc: "Nessa problemática, toda a especificidade da América Latina foi implicitamente negada, e o continente concebido como uma espécie de Europa tropical, com seu desenvolvimento retardado de um século, e sob o domínio do império norte-americano" (LÖWY, 1999, p.11).

Por outro lado, na primeira geração de marxistas latino-americanos forjados pela Revolução Russa, tivemos alguns exemplos que contrariavam essa norma geral e buscaram estabelecer interpretações com novos aportes ao pensamento marxista. Se Mariátegui seria aquele que apresentaria tal capacidade inovadora de forma mais sistemática, houve outros que também apresentariam a mesma disposição, dentre os quais destaca-se Julio Antonio Mella, jovem intelectual cubano, assassinado no México em 1929. Mella desenvolveu uma apurada análise crítica do imperialismo, e em particular das formas possíveis de luta e resistência,

18 Como a obra Agrarismo e industrialismo (1928) do brasileiro Octavio Brandão.

\section{GANPHLAC}

Revista Eletrônica da ANPHLAC, ISSN 1679-1061, №. 25, p. 87-115, Jul./Dez., 2018.

http://revista.anphlac.org.br 
além de uma profícua aproximação com a cultura popular na análise da realidade de Cuba ${ }^{19}$. Um outro exemplo dessa originalidade pode ser encontrado de forma mais pontual em Ricardo Paredes, dirigente da esquerda no Equador e um dos fundadores do Partido Socialista Equatoriano, em 1926. Divergindo da visão dominante na Internacional Comunista, que classificava a América Latina como uma sociedade "colonial" ou "semicolonial", Paredes defendia que os países latino-americanos fossem reconhecidos como "países dependentes” em referência às suas estruturas socioeconômicas ${ }^{20}$.

Mesmo não sendo predominante, a ocorrência dessas manifestações não-dogmáticas sugerem como o marxismo latino-americano em seus primeiros voos originais, tiveram uma influência na experiência soviética. No período anterior, quando o marxismo hegemônico tinha sua matriz intelectual na Internacional Socialista dirigida pela social-democracia alemã de Karl Kautsky, os escritos de marxistas latino-americanos, em termos heurísticos, eram de uma originalidade quase inexistente. A experiência revolucionária russa despertaria uma ousadia intelectual que marcaria a geração de 1920, que, não por acaso, terá na crítica à geração anterior, um de seus pilares. Esse aspecto passará a se mostrar possivelmente melhor delineado a partir do exame do pensamento de Mariátegui.

\section{Mariátegui e o marxismo}

José Carlos Mariátegui integra a primeira geração de marxistas latino-americanos que vivenciariam os efeitos imediatos da revolução. Ele aderiu ao marxismo como consequência de sua quase imediata identificação aos propósitos transformadores irradiados pela vitória bolchevique. Essa identificação, cujos efeitos em sua produção intelectual veremos adiante, jamais seria abandonada, reivindicando até o fim de sua vida a filiação ao marxismo. A Revolução bolchevique era, para Mariátegui, o acontecimento de maior transcendência do século XX, que deslocava a possibilidade da revolução social do campo das hipóteses para uma situação concreta e factível. Lenin, o condutor da "revolução heroica", era a expressão

19 Como no artigo que escreveria sobre José Martí, em que busca conectar o exemplo de sua luta pela independência cubana com as lutas do presente, afirmando que "orgánicamente revolucionario, fue el intérprete de una necesidad social de transformación en un momento dado. Hoy, igualmente revolucionario, habría sido quizás el intérprete de la necesidad social del momento" (MELLA [1926], 2008, p.37), esta necessidade do momento, sustentaria Mella, estaria na revolução comunista. Esta conexão com o uso da figura popular de José Martí em Cuba seria posteriormente também utilizada por Fidel Castro e o PC cubano.

20 Cf. PAREDES, [1926] 2011, p.14.

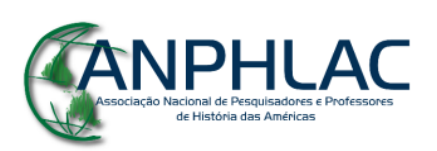

Revista Eletrônica da ANPHLAC, ISSN 1679-1061, №. 25, p. 87-115, Jul./Dez., 2018.

http://revista.anphlac.org.br 
maior do que seria a superação do reformismo parlamentar da Segunda Internacional e seu evolucionismo positivista.

Nascido em 1894 na cidade de Moquegua, no sudeste do Peru, Mariátegui foi um intelectual autodidata que exerceu o jornalismo como ofício. Trabalhando desde a sua juventude em diversos periódicos peruanos, a partir de 1914 teria uma contínua produção periodista, principalmente na área da crítica cultural e de temas da política cotidiana, na qual ganharia ainda jovem destaque na imprensa limenha.

Sua virada política se daria alguns anos depois, como ele próprio relataria: "A partir de 1918, nauseado da política criolla, me orientei resolutamente em direção ao socialismo, rompendo com minhas primeiras tentativas de literato contaminado de decadentismo e bizantinismo finisseculares, em pleno apogeu." (MARIÁTEGUI, [1927] 2000, contracapa). Mas, ao contrário do que o próprio Mariátegui gostaria de fazer crer, sua "guinada à esquerda" não foi propriamente uma ruptura. Na verdade, sua mudança política começa lentamente alguns anos antes, ainda em sua fase "decadentista", quando entra em contato com González Prada ${ }^{21}$, acompanhando algumas greves e protestos operários, participando de reuniões de grupos anarquistas e socialistas e sendo eleito vice-presidente do "Círculo de Periodistas".

Após a revolução russa, no período de 1918 e 1919, os artigos de Mariátegui assumiriam um tom cada vez mais incendiário, assim como sua simpatia pelo novo regime soviético ampliava-se. Essa mudança política não se faria sem consequências, adotando um engajamento crescente com relação aos temas sociais do período em Lima, com destaque para seu envolvimento na luta por uma reforma universitária. Suas críticas públicas ao golpe de estado impetrado por Augusto Léguia não passam incólume e ele acaba tendo de exilar-se na Europa, onde ficaria do final de 1919 até meados de 1923. É ao longo dessa sua incursão pelo velho continente que completaria a sua formação teórica marxista.

Fixando residência durante a maior parte de seu exílio na Itália, Mariátegui manteria uma contínua produção de artigos durante tal período. Em fevereiro de 1920, poucos meses após a sua chegada em Roma escreveria A entente e os Sovietes, obra na qual analisa a relativa abertura dos países ocidentais em relação a Rússia, afirmando não ser este gesto uma

21 A importância de González Prada (1844-1918) para o cenário político e cultural peruanos do final do século XIX é notável. Poeta e ensaísta, seria um dos percursores do modernismo no Peru, crítico mordaz da igreja católica, ao final de sua vida aderiria ao anarquismo proudhoniano.

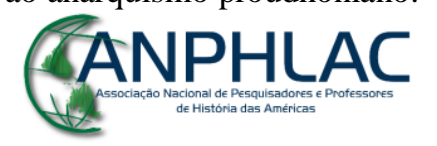

Revista Eletrônica da ANPHLAC, ISSN 1679-1061, №. 25, p. 87-115, Jul./Dez., 2018.

http://revista.anphlac.org.br 
concessão, mas o reconhecimento da força do regime socialista e da imperiosa necessidade de comercializar com o maior produtor de grãos do mundo. Esse artigo não seria o único, sendo que voltaria diversas vezes a analisar a conjuntura soviética, como nos artigos Rússia e Polônia (outubro de 1920), A fome na Rússia (agosto de 1921) e O crepúsculo da civilização (dezembro de 1922).

Em 1923, Mariátegui encerraria seu exílio e regressaria ao Peru. Em sua volta, além de retornar às suas atividades como jornalista, se reaproximaria do movimento estudantil, no qual buscaria pôr em prática aquela que ele afirmava ser sua "missão": construir o socialismo peruano. Nesse sentido, em julho de 1923, ministraria uma conferência sobre a Revolução Russa na sede da Federação dos Estudantes do Peru, vínculo este que se estreitaria levando-o a passar um período ministrando aulas na Universidade Popular González Prada, criada por Haya de la Torre com o objetivo de estabelecer um diálogo entre estudantes e operários. Mariátegui proferiu aulas sobre a história da crise mundial a partir de sua vivência europeia e sobre a URSS.

Desde sua volta em 1923 até o seu falecimento precoce em 1930, é nítido o caráter agonístico - no sentido dado por Mariátegui - em seu pensamento e ação revolucionária ${ }^{22}$. Sua atuação política seria intensa, seja integrando a Aliança Popular Revolucionária Americana (APRA) ${ }^{23}$; liderando a criação da Confederação Geral do Trabalho do Peru $(\mathrm{CGTP})^{24}$, ou ainda na fundação Partido Socialista Peruano (PSP), após seu rompimento com a APRA, em 1928, sendo eleito seu primeiro secretário-geral. Como periodista, Mariátegui fundaria a revista Amauta $^{25}$, publicação que unia textos culturais e políticos e pretendia ser "a voz de uma geração" colocando o Peru "no seio do panorama mundial". Outra iniciativa sua foi a criação do jornal Labor, dedicado ao sindicalismo e ao mundo do trabalho. Em vida, Mariátegui publicaria dois livros, seu primeiro, A cena contemporânea, de 1925, era uma coletânea de artigos publicados na imprensa. Seu segundo e principal livro, os Sete ensaios de

22 Mariátegui, recuperando conceito do poeta e filósofo espanhol Miguel de Unamuno, defendia que: "a palavra 'agonia', na viva e ardente linguagem de Unamuno, recupera sua acepção original. Agonia não é prelúdio da morte, não é conclusão da vida. Agonia (...) quer dizer 'luta'. Agoniza aquele que vive lutando lutando contra a própria vida. E contra própria morte.” ([1926] 1977, p.116).

23 A APRA seria fundada em 1924, no México, por Haya de La Torre, com o objetivo de constituir-se numa frente de forças anti-imperialistas na América Latina.

24 Movimento que representava a separação definitiva entre os socialistas e o anarcossindicalismo peruano.

25 A palavra Amauta é de origem quéchua e significa mestre, pensador. Como fundador da revista, José Carlos Mariátegui passaria também a ser conhecido e recordado como o Amauta.

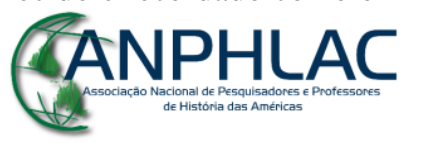

Revista Eletrônica da ANPHLAC, ISSN 1679-1061, №. 25, p. 87-115, Jul./Dez., 2018.

http://revista.anphlac.org.br 
interpretação da realidade peruana, publicado em 1928, se converteria, décadas depois, em um dos clássicos do pensamento crítico latino-americano.

O grande mérito dos Sete ensaios está em buscar uma análise da sociedade peruana empregando o arcabouço teórico do marxismo, no qual opera de forma criativa uma dialética do singular e do universal, ou seja, utilizando-se do instrumental marxista, supera os limites da dicotomia entre um particularismo ou excepcionalismo latino-americano, por um lado, e de um universalismo eurocentrista por outro. Em decorrência, não dispondo de recursos teóricos que respondessem adequadamente a seus questionamentos, desenvolve importantes inovações metodológicas que lhe conferem uma originalidade analítica, na qual esse olhar para a especificidade dos aspectos locais se articulava em uma perspectiva que abarca uma universalidade da teoria.

A influência dos marxistas russos nos Sete ensaios estaria presente, em certa medida, desde a concepção geral da obra, mas, principalmente, em sua principal hipótese: a viabilidade de um caminho revolucionário para a América Latina e em particular para o Peru. Essa hipótese apoiava-se no exemplo russo, país predominante agrário e industrialmente atrasado, a exemplo das sociedades latino-americanas, e que pôde romper com o atraso do czarismo sem necessitar de uma etapa capitalista em seu desenvolvimento, buscando diretamente uma emancipação socialista. Com essa perspectiva, Mariátegui superava uma noção, até então muito difundida, da necessidade de "etapas históricas" a serem seguidas pelos povos de forma indistinta, etapas estas que espelhavam-se mecanicamente no processo de evolução histórica dos países centrais da Europa.

Esse aspecto político da via revolucionária, ainda que consonante com o marxismoleninismo, seria também influenciado pelas ideias de Georges Sorel ${ }^{26}$. O impacto do autor de Reflexões sobre a violência em Mariátegui inspiraria um dos elementos-chave de seu conceito de socialismo indo-americano, que é a noção de Mito enquanto elemento fundante para uma revolução, reintroduzindo uma dimensão metafísica ao socialismo. Assim como seu libelo à Ação, expresso no voluntarismo que, por vezes, Mariátegui manifestava em oposição ao gradualismo da social-democracia.

26 Georges Sorel (1847 - 1922), marxista heterodoxo, foi um teórico francês do sindicalismo revolucionário, de extrema-esquerda, crítico à ação parlamentar, que seria influenciado por autores como Proudhon e Marx, mas também por Ernest Renan e Nietzsche. Com uma trajetória política um tanto errática, flertou por algum tempo com a extrema-direita monarquista, no fim da vida se reconciliou com a esquerda a partir de sua admiração por Lenin.

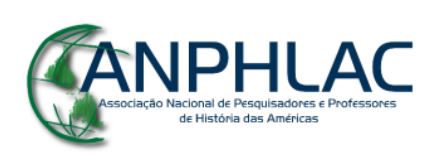

Revista Eletrônica da ANPHLAC, ISSN 1679-1061, №. 25, p. 87-115, Jul./Dez., 2018.

http://revista.anphlac.org.br 
Devido a este último aspecto, Mariátegui daria um relevo desproporcional aos traços voluntaristas subjacentes ao comunismo russo. Escreve, por exemplo, em Defesa do marxismo: "Atribui-se a Lenin uma frase que foi celebrada por Unamuno em seu Agonia do cristianismo: a que pronunciou certa feita, em resposta a alguém que afirmava que seu esforço entrava em contradição com a realidade: 'tanto pior para a realidade!"” ([1927] 2011, p.60). Essa passagem exemplifica alguns dos contornos do seu leninismo: "Se é verdade que o bolchevismo contém uma dose considerável de voluntarismo, o Lenin 'quixotesco' de Mariátegui (...) é, em última análise, uma criação imaginária” (LÖWY, 2005, p.18).

Tal apropriação criativa é consonante com a forma como concebia o socialismo na América Latina, que seria um esforço de "criação heroica". A presença de Sorel, assim como de outras fontes e autores pouco usuais (ou polêmicos) entre os marxistas de sua época, compõe a abertura teórica e a postura não sectária de Mariátegui ${ }^{27}$. Mas aqui nos interessa destacar seu conhecimento e sua apropriação da literatura que compunha o então nascente marxismo-leninismo. Com base no trabalho de Harry Vanden (1975), que realizou uma detalhada pesquisa sobre a biblioteca do autor, sabemos que além de algumas das principais obras de Lenin, ele também possuía livros de Leon Trotski, Karl Radek, Bukharin, Zinoviev, entre outros autores bolcheviques, muitos adquiridos durante seu exílio. Será dessa clivagem, tendo os marxistas russos uma relevância significativa que, de certa forma, é beneficiada a compreensão de suas inovações teóricas, assim como alguns de seus limites.

Importante destacar que tanto as noções de marxismo-leninismo ou apenas leninismo, naquele momento, não possuem o mesmo sentido que tais termos viriam a ganhar anos depois com o corpo teórico desenvolvido pela III $^{\mathrm{o}}$ Internacional, convertido em uma rígida doutrina oficial do regime soviético. Responde aqui a uma dupla dimensão: primeiramente relacionada a uma práxis revolucionária, por vezes interpretada quase que como uma "receita" para a revolução; e/ou também por certa fidelidade ou simpatia à "tradução russa" do marxismo, o atualizando, por assim dizer, às especificidades locais e mesmo demonstrando a possibilidade do marxismo ser "traduzido" para outras realidades ${ }^{28}$.

27 Para um debate sobre as fontes e influências teóricas de Mariátegui, ver PARIS (1981), VANDEN (1975) e QUIJANO (2007), entre outros.

28 A percepção de uma "russificação do marxismo" seria analisada, entre outros, por Gramsci, que em 1926 apontaria que "se se estuda o esforço realizado desde 1902 até 1917 pelos majoritários (bolcheviques), se vê que sua originalidade consiste em uma depuração do internacionalismo, extirpando dele todo elemento vago e puramente ideológico (em sentido pejorativo) para dar-lhe um conteúdo realista" (1977, p.341).

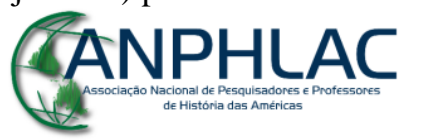

Revista Eletrônica da ANPHLAC, ISSN 1679-1061, №. 25, p. 87-115, Jul./Dez., 2018.

http://revista.anphlac.org.br 


\section{Um passo adiante: o socialismo indo-americano}

Mariátegui se desafiou a refletir um socialismo que, ao mesmo tempo que se valeria do melhor da "ciência e do pensamento europeus e ocidentais", não deveria ser "nem decalque nem cópia", mas sim uma criação original. Mantendo-se no âmbito do leninismo, o revolucionário peruano ao propor um socialismo indo-americano, consigna que talvez melhor sintetize o conjunto de suas elaborações originais, promovia um verdadeiro "passo adiante" para a construção de um marxismo latino-americano.

Sua perspectiva socialista para a América Latina buscava apoiar-se nos elementos localmente presentes, adaptando o aporte interpretativo do marxismo para as especificidades de uma estratégia revolucionária no mundo não europeu e pós-colonial. Nessa empreitada, destaca-se um aspecto singular em sua elaboração, e com profundas implicações: o indígena como sujeito na revolução socialista.

Partindo de um diagnóstico da sociedade peruana, em seus múltiplos aspectos, examinaria a forma como o indígena - elemento demográfico majoritário - era brutalmente excluído e sistematicamente aviltado. Diferentemente de muitos de seus contemporâneos, que apostavam no acesso à educação como forma de promover maior justiça social para os povos indígenas, Mariátegui rejeitaria tal alternativa e apontaria que a resolução da condição de exploração do índio seria econômica e social, e passaria fundamentalmente pela questão da posse da terra: "Colocando no primeiro plano o problema econômico-social, assumimos a postura menos lírica ou literária possível. Não nos contentamos em reivindicar o direto do índio à educação, à cultura, ao progresso, ao amor e ao céu” (MARIÁTEGUI, [1928], 2008, p.67-68). Afirmando uma posição resolutamente materialista para a questão, rompia com certa apologética que aduzia o problema indígena em termos ético-morais.

Mariátegui identificou que o centro do poder de classe peruano provinha em grande medida da propriedade da terra, herdada do período colonial de forma quase inalterada, conferindo a classe proprietária uma condição privilegiada para a reprodução de sua dominação. O caminho que ele propunha para enfrentar os problemas agrário e indígena passava pelo socialismo, cuja "sobrevivência da comunidade e de elementos de socialismo prático na agricultura e vida indígenas” (MARIÁTEGUI, [1928], 2008, p.69), confeririram a tal consigna condições de efetividade. Seria dessa capacidade de resiliência das comunidades indígenas, de seu passado e presentes comunitários e coletivistas que se estabeleceriam as

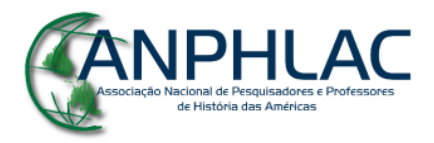

Revista Eletrônica da ANPHLAC, ISSN 1679-1061, №. 25, p. 87-115, Jul./Dez., 2018.

http://revista.anphlac.org.br 
condições de viabilidade para a construção do socialismo. Para Mariátegui, "a solução do problema do índio tem que ser uma solução social. Seus realizadores devem ser os próprios índios" ([1928], 2008, p.66). Desta forma, indicava ao indígena uma condição de protagonismo para o socialismo indo-americano.

Sem abandonar a importância e centralidade do proletariado para a construção do socialismo, esse seu movimento intelectual seria um esforço que ele apontaria como de "transcendência" do marxismo para a sua realidade. Diretamente influenciado pelo indigenismo radical peruano ${ }^{29}$ e impactado pelas mobilizações indígenas daquele período ${ }^{30}$, para Mariátegui era uma condição evidente a importância da questão indígena para um projeto de "interpretação e transformação da realidade", por todo seu passado e presente de exclusão bem como por ser uma questão que representava "o problema de três quartos da população do Peru". Para além de todos esses aspectos, a centralidade do indígena se justificaria para a existência de um "comunismo incaico", praticado durante o Império Tawantinsuyu ${ }^{31}$, cujas reminiscências se mostravam em sua organização social baseada em uma cultura coletivista estreitamente ligada à terra e que para o pensador peruano seria um elemento específico que viabilizaria um projeto socialista na Indo-América. Afirmaria que "o ayllu ${ }^{32}$, célula do Estado incaico, sobrevivente até agora, apesar dos ataques da feudalidade e do gamonalismo, ainda denota suficiente vitalidade para converter-se gradualmente na célula de um Estado socialista moderno" (MARIÁTEGUI [1928], 2008, p.117).

Assim, Mariátegui buscou elaborar uma análise que incorporasse o elemento indígena no centro de uma perspectiva marxista revolucionária. Tendo bases explicativas não apenas nos elementos conjunturais das lutas indígenas, Mariátegui pôde acompanhar, mas também em elementos historicamente forjados, cujas ocorrências ainda persistiriam. Seria a partir desse aporte conceitual que Mariátegui, “ainda dentro da clássica esquematização da evolução histórica em cinco modos de produção do marxismo desta época, antes do redescobrimento do conceito de modo de produção asiático em Marx, que admitiu a tese do carácter comunista

29 Dentre os indigenistas com os quais Mariátegui tomaria contato em suas pesquisas, como Hildebrando Castro Pozo, foi Luis E. Valcárcel, a maior influência e proximidade. Valcárcel foi autor de Tempestad en los Andes, obra em que defende o renascimento indígena pela via da insurreição, que acreditava ser eminente, faltando apenas uma liderança revolucionária, como afirmaria: “o proletariado indígena espera seu Lênin". Esta obra seria publicada pelo próprio Mariátegui em seu editorial Minerva, em 1927, que ele ainda escreveria o prólogo desta edição. Posteriormente, Valcárcel seria um dos mais conhecidos antropólogos peruanos.

30 Como a rebelião liderada por Rumi Maqui, em 1915, em Huancané e Azángaro.

31 Denominação dada pelos incas ao seu império. A palavra em quéchua significa "os quatro cantos do mundo". 32 O ayllu é a forma incaica da "comunidade", que é constituída a partir de estruturas de parentesco.

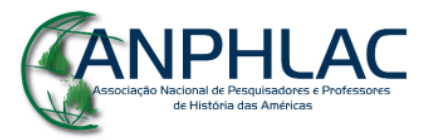

Revista Eletrônica da ANPHLAC, ISSN 1679-1061, №. 25, p. 87-115, Jul./Dez., 2018.

http://revista.anphlac.org.br 
primitivo da sociedade incaica" (QUIJANO, 2007, p.84). Esses elementos comunais resgatados, passaram por um reconhecimento crítico, identificando o seu limite no despotismo teocrático do Estado Inca $^{33}$. É possível identificar nessa elaboração um componente da influência russa, seja pela forma como analisou a questão agrária e da posse da terra, seguindo alguns dos caminhos e intuições de Lenin sobre a sociedade rural russa, ou ainda, mas com alguma reserva, sobre a transição do socialismo junto ao campesinato.

Tal caracterização e importância dadas ao aspecto comunista das antigas comunidades agrárias não eram totalmente estranhas ao marxismo, ainda que naquele momento não tenham sido suficientemente desenvolvidas. Com sensíveis diferenças, a tese guarda semelhanças com o programa agrário dos Socialistas Revolucionários $(\mathrm{SR})^{34}$, noção rejeitada pelos bolcheviques, porém posteriormente incorporada de forma parcial às portas da revolução a partir da defesa da reforma agrária, efetivada pela nacionalização dos latifúndios. Não houve nenhuma influência direta das posições dos SR's com o paralelismo elaborado por Mariátegui entre o comunismo incaico e as comunas russas ${ }^{35}$, na verdade, guardaria semelhanças maiores na forma como foram tratadas em alguns escritos de Marx, nos quais apontava as comunas rurais russas como possíveis formas embrionárias de organização socialistas ${ }^{36}$. Até em que medida essa leitura de Mariátegui é diretamente influenciada por esse aspecto do pensamento de Marx é algo difícil de precisar, mas, até o ponto em que nossa pesquisa pôde apurar, foi inexistente. O peruano chegaria a conclusões próximas às de Marx por outros caminhos.

O fio condutor aqui seria seu rompimento com a linearidade e teleologia histórica disseminadas na cultura marxista de então, particularmente na Internacional Socialista de Kautsky e sua ortodoxia, mas igualmente na Internacional Comunista. Rompia assim com certa passividade, derivada da crença no "progresso inelutável da história". Com essa perspectiva, Mariátegui seria um dos primeiros marxistas a desenvolver um aporte teórico

33 Cf. MARIÁTEGUI [1928] (2008, p.92).

34 Essa semelhança, sem observar as sensíveis diferenças das proposições de Mariátegui, como o papel que ele conferia ao operariado urbano, levaria o especialista soviético em América Latina, M. Miroshevsky, em um artigo no qual abertamente buscava detratar o autor peruano, a acusá-lo de defender posições populistas como também eram chamados os SRs - em decorrência de tal posição, classificou Mariátegui como "propagandista do socialismo pequeno-burguês".(MIROSHEVSKY, [1942], 1978. p.58).

35 Mariátegui traçaria abertamente o paralelo entre o Peru e a Rússia, enquanto sociedades rurais com certas características coletivistas, por exemplo, nos Sete Ensaios... ([1928], 2000, p.64).

36 Um exemplo é o prefácio de Marx e Engels à tradução russa do Manifesto Comunista, publicada em 1882, no qual apontavam que "se a revolução russa se tornar o sinal de uma revolução proletária no Ocidente, de tal modo que ambas se completem, a atual propriedade comum russa do solo pode servir de ponto de partida de um desenvolvimento comunista" (MARX \& ENGELS, 2012, p.104-105).

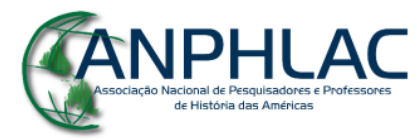

Revista Eletrônica da ANPHLAC, ISSN 1679-1061, №. 25, p. 87-115, Jul./Dez., 2018.

http://revista.anphlac.org.br 
cuja concepção histórica se assentava em bases não-eurocêntricas. Ele compreendia ao "marxismo como um instrumento de análise produtivo e não como uma teoria apriorística meramente descritiva de um modelo universal, que supostamente deveria aplicar-se de maneira subsidiária - como até o momento se havia feito - na América Latina" (KOHAN, 2014, p.29).

\section{Uma síntese da influência bolchevique em Mariátegui}

Para além do que já foi aqui colocado, uma influência fundamental para Mariátegui herdada dos revolucionários russos seria sua interpretação do fenômeno do imperialismo. $\mathrm{O}$ peruano incorporaria em boa medida as formulações elaboradas por Lenin em sua obra Imperialismo: fase superior do capitalismo, de 1917, as quais orientariam o conjunto de iniciativas políticas desenvolvidas por ele no enfrentamento ao imperialismo na América Latina. Perceptível desde seu ingresso na APRA, e depois em seu rompimento com essa organização, na qual explicitaram-se as diferenças sobre a caracterização do imperialismo entre Mariátegui e Haya de La Torre ${ }^{37}$, e ainda, por fim, no ingresso do Amauta em 1928 nas fileiras da Liga contra o Imperialismo, organização fundada um ano antes em Bruxelas e afiliada à Internacional Comunista ${ }^{38}$.

Essa perspectiva crítica sobre o imperialismo e sua importância para as sociedades latino-americanas estará presente de forma transversal na obra de Mariátegui. Para ele a luta contra o imperialismo na América Latina colocava como resposta um apelo ao internacionalismo revolucionário ligado a uma opção classista de enfrentamento ao imperialismo $^{39}$, o que justifica suas ações políticas e sua preocupação permanente com a conjuntura internacional. Será guiado por tal perspectiva que dedicará inúmeros esforços em divulgar as conquistas soviéticas e a defender de seus detratores.

Mariátegui escreveu dezenas de artigos sobre a conjuntura soviética e de divulgação do perfil dos principais líderes bolcheviques (Lenin, Trotsky, Zinoviev, Lunatcharsky, entre outros), além de dedicar especial atenção à cultura e às artes russas, em particular sobre a

37 Essas diferenças seriam sintetizadas por Mariátegui no documento Ponto de vista antiimperialista, de 1929.

38 Mariátegui seria eleito ao Conselho Geral da Liga no II Congresso da entidade, em 1929.

39 O APRA de Haya defendia alianças com setores nacionalistas da burguesia e submissão do proletariado a este, do que Mariátegui discordava, tanto por não identificar qualquer nacionalismo nas burguesias locais, como por entender que a condução da revolução deveria se dar pelos setores oprimidos pelo capitalismo.

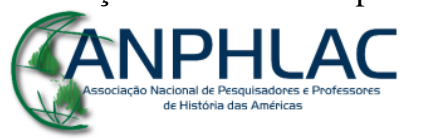

Revista Eletrônica da ANPHLAC, ISSN 1679-1061, №. 25, p. 87-115, Jul./Dez., 2018.

http://revista.anphlac.org.br 
literatura, a partir da qual não escondia sua admiração por autores (clássicos e contemporâneos) tais como Maiakovski, Gogol, Tolstói, Dostoiévski, Serge, Gorki, entre outros. Nas páginas de sua revista Amauta, dedicaria inúmeros esforços para a difusão desses autores no cenário cultural peruano.

Em uma análise crítica de seus escritos dedicados à conjuntura da URSS ou às descrições e análises dos personagens da revolução, estas eram um tanto unidimensionais, deixando de mostrar as particularidades e seus problemas intrínsecos, seja em relação ao seu caráter ou à sua personalidade, ou ainda de seus aspectos teóricos ou políticos (PERICÁS, 2012, p. 33). Tal postura pode ser em parte explicada por se tratarem, na maioria, de textos publicados na grande imprensa limenha e deve-se reconhecer certos limites de sua leitura que possivelmente se conectam às disputas ideológicas de seu tempo, quando a Revolução Russa representava um importante ideal de transformação para diversos movimentos operários e socialistas ao redor do mundo e era sistematicamente atacada pela imprensa burguesa.

Um aspecto polêmico da relação de Mariátegui com a revolução russa diz respeito à maneira com a qual ele teria se posicionado frente às disputas pelo poder na União Soviética, abertas após a morte de Lenin, e à divisão entre os partidários de Stalin contra os de Trotsky. A grande maioria de seus artigos assumia uma perspectiva otimista e muitas vezes francamente laudatória face aos acontecimentos e personagens da revolução, mas, mesmo com tal ressalva, Mariátegui teceu comentários críticos pontuais e, em grande medida, tomaria posição frente às disputas internas dos bolcheviques.

Mariátegui expressou em diversas oportunidades sua admiração pela liderança e capacidade intelectual de Trotsky, o considerava "um dos personagens mais interessantes da história contemporânea: condottiere da Revolução Russa, organizador e animador do Exército Vermelho, pensador e crítico brilhante do comunismo" ([1925] 1988, p.149). No entanto, tal reconhecimento e respeito pelo líder do Exército Vermelho não deve ser extrapolado, o peruano estaria longe de ser classificado como um "trotskista". Assim como buscar enquadrálo como um "stalinista" é igualmente errôneo. Mariátegui estava bem informado sobre as disputas internas dos bolcheviques (mesmo com as dificuldades de acesso a muitos dos documentos que animavam a polêmica) e ainda que compreendendo a gravidade e

\section{GANPHLAC}


importância do cisma entre as lideranças soviéticas ${ }^{40}$, de certa forma subestimou suas consequências e efeitos a médio prazo ${ }^{41}$.

Mariátegui via justeza nos argumentos e proposições trotskistas, em particular a defesa da democratização do partido e a crítica a burocratização. No entanto, com relação a temas como a política agrária e industrial, não via a oposição capaz de condensar em fórmulas concretas, da mesma forma, ainda que identifica-se em Trotsky aquele capaz de melhor identificar a "transitória estabilização do capitalismo" e a possibilidade de uma nova onda de revoluções pelo globo. Seria justamente essa dimensão internacionalista que o enfraqueceria, o peruano compreendia que o momento não se tratava de estabelecer o socialismo no mundo, mas de realizá-lo em uma nação, características que Stalin, "um eslavo puro", encarnaria. Seria por identificar um maior senso de realidade na maioria do partido organizado em torno da liderança de Stalin, que levaria Mariátegui a compreender naquele momento e, em certa medida, apoiar tal desfecho. Além disso, e talvez de forma mais decisiva, Mariátegui acreditava que a crise não engendraria um cisma profundo no partido, pois a "velha guarda bolchevique" já teria dado "explicitamente sua adesão à tese da necessidade de democratizar o partido" ([1925] 1988, p.154-155). Sabemos hoje que as previsões otimistas de Mariátegui não concretizaram-se e o processo que seguiu-se foi na direção oposta, ocorrendo um fechamento político ainda maior, acompanhado de expurgos e perseguições a todo e qualquer dissenso no seio do partido bolchevique.

Mariátegui não viveria tempo suficiente para tomar conhecimento dos crimes de Stalin, mas sofreria os efeitos do início da stalinização. Em 1929, buscando estabelecer uma maior presença na América Latina, a Internacional Comunista realizaria a $\mathrm{I}^{\mathrm{o}}$ Conferência Comunista Latino-americana, em Buenos Aires, à qual o PSP de Mariátegui seria convidado e participaria $^{42}$. A delegação peruana apresentaria os documentos do programa político do PSP e as teses $O$ problema das raças na América Latina e Ponto de vista antiimperialista, ambas

40 Escreveria "Nunca a queda de um ministro teve no mundo uma ressonância tão extensa e tão intensa como a queda de Trotsky. O parlamentarismo habituou o mundo às crises ministeriais. A queda de Trotsky, contudo, não é uma crise de governo, mas uma crise de partido.” ([1925] 1988, p.149)

41 Ele afirmaria, a respeito do exílio de Trotsky, que "sensatamente, o que não devia jamais se esperar é que a empresa de organizar o primeiro grande Estado socialista fosse cumprida por um partido de mais de um milhão de militantes apaixonados (com o acordo da maioria mais um), sem debates nem conflitos violentos". (MARIÁTEGUI, [1929] 1986, p.27)

42 Devido ao agravamento de problemas de saúde, Mariátegui é impossibilitado de participar, mas uma delegação representaria o nascente PSP, formada por Hugo Pesce e Julio Portocarrero.

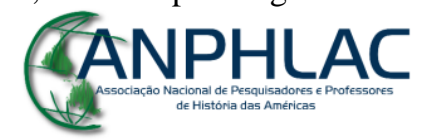

Revista Eletrônica da ANPHLAC, ISSN 1679-1061, №. 25, p. 87-115, Jul./Dez., 2018.

http://revista.anphlac.org.br 
redigidas em sua quase totalidade por Mariátegui ${ }^{43}$. As políticas expressadas nesses documentos, assim como sua concepção de partido e do carácter do programa estratégico da revolução peruana, entram em forte polêmica com a direção oficial da III $^{\circ}$ Internacional nessa reunião (QUIJANO, 2007, p.48). Nenhuma das teses de Mariátegui seria acolhida e o ingresso do PSP na Internacional Comunista seria rejeitado, sendo apenas membros convidados. A sugestão proposta para ter o ingresso aceito seria a dissolução do PSP e a fundação de um partido comunista "verdadeiro", proposta rejeitada por Mariátegui. ${ }^{44 .}$

Essa diferença não era restrita a mera formalidades, mas envolvia a própria concepção de partido e a possibilidade de adaptação (ou não) a realidades distintas. Podemos percebê-la de forma mais nítida ao observarmos o manifesto programático do PSP, documento no qual o PSP expressou sua filiação ao marxismo-leninismo, justificada como sendo "o método revolucionário da etapa do imperialismo e dos monopólios", e assim adota-o "como método de luta" (MARIÁTEGUI, [1928] 1971, p.160). O fato de o partido ter a denominação socialista e não comunista, como defendido pela Internacional Comunista, não seria casual, mas fruto de uma leitura em que as condições para estabelecer um partido com tal delimitação, na conjuntura peruana, estreitaria seu raio de ação. Esse aspecto fica evidente quando no mesmo documento de fundação do partido, colocou-se o PSP como representante da luta política das "massas trabalhadoras da cidade, do campo, das minas e do campesinato indígena" (idem, p.164), conformando um partido cujo centro seria uma aliança entre as classes oprimidas pelo capital, "um partido, portanto, que não correspondia exatamente ao modelo de partido uniclassista proletário, da Terceira Internacional” (SÁNCHEZ VÁSQUEZ, 1998, p.54).

Em 1930, as posições de Mariátegui no interior do Comitê Central do PSP se enfraquecem e sua defesa de uma maior autonomia partidária começaria a ceder lugar às teses emanadas de Moscou. Como consequência da disputa interna, Mariátegui renunciou ao posto de secretário-geral do partido, sendo substituído por Eudocio Ravines, que àquela altura integrava a direção latino-americana da Internacional. Sua saúde se agrava, sendo que viria a falecer internado em um hospital em 16 de abril. Pouco depois, em 20 de maio, o PSP é dissolvido, convertendo-se no Partido Comunista do Peru (PCP).

43 A tese "O problema das raças na América Latina" contou com o auxílio de Hugo Pesce na redação final. 44 Para um exame pormenorizado da polêmica entre Mariátegui e Komintern ver FLORES GALINDO, 1981.

\section{GANPHLAC}


Para além de aspectos politico-organizativos, esse episódio revela algumas das diferenças existentes na concepção do socialismo para a América Latina. A defesa desenvolvida por Mariátegui de que a revolução socialista poderia se dar em contextos de baixa industrialização seria inequivocamente tributária do exemplo prático de Lenin e a exitosa revolução bolchevique em um dos "elos mais fracos" do capitalismo. Posteriormente, essa noção seria sensivelmente matizada pelo próprio bolchevismo ao longo das décadas de 1920 e 1930, colocando as posições de Mariátegui em desalinho com o marxismo hegemônico. Para além das viradas táticas conjunturais da Internacional Comunista ${ }^{45}$, não devem ser menosprezados os aspectos eurocêntricos reproduzidos pelos bolcheviques.

A linearidade evolutiva da história, tão cara ao marxismo da geração da Segunda Internacional, foi atualizada pelo stalinismo a partir de sua noção própria de etapas, que funcionavam como pressuposto invariável e simplificador da realidade, dentro do esquematismo da chamada lei dos Cinco Estágios de Stalin ${ }^{46}$, no qual "se transporta por decreto o modelo europeu para o planeta inteiro" (AMIN, 1989, p. 114). Na oposição trotskista, no interior do bolchevismo, igualmente se vislumbram posições profundamente eurocêntricas, ainda que com significativas inflexões. Na teoria da Revolução Permanente, postula-se a viabilidade da revolução socialista ocorrer em países "atrasados", prevendo a possibilidade de se "pular" as etapas preliminares ao socialismo ${ }^{47}$, desde que inseridas na revolução mundial. No entanto, mais do que apenas um compromisso com o internacionalismo em oposição ao "russocentrismo" de Stalin, tal abertura de Trotsky para a defesa da revolução em países não-ocidentais conservou, em paralelo, a noção do Ocidente como modelo único de desenvolvimento, cabendo aos países coloniais ou semicoloniais, mesmo após uma revolução de caráter socialista, seguir de forma combinada esse mesmo itinerário $^{48}$. Trotsky mantinha também uma firme convicção de que o sucesso do socialismo na Europa subordinava o restante do planeta, sendo esta uma condição para a própria

45 Seria após VI Congresso da III Internacional, em 1928, que, por exemplo, a teoria do socialismo em um só país passa a ser o princípio diretor da concepção da revolução mundial, oficialmente submetida aos movimentos táticos e diplomáticos da URSS (CLAUDIN, 2013, p.94-95).

46 Nela Stalin afirmava haver uma lei universal na história, na qual todas as sociedades, os modos de produção se sucederiam em cinco estágios sucessivos: comunismo primitivo - escravidão - feudalismo - capitalismo socialismo.

47 Era corrente na Internacional Comunista diferenciar aos países como "maduros" ou "não maduros" ao socialismo, com base no percurso destes em cumprirem previamente as "etapas" necessárias para a transição socialista.

48 Cf. TROTSKY, 1977, p.203-207.

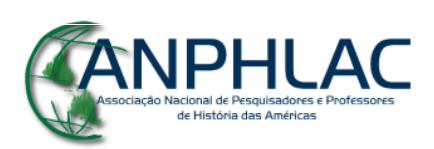

Revista Eletrônica da ANPHLAC, ISSN 1679-1061, №. 25, p. 87-115, Jul./Dez., 2018.

http://revista.anphlac.org.br 
continuidade da existência da URSS ${ }^{49}$.

Dessa perspectiva, causa menos estranheza o fato de que, na década de 1930, tanto stalinistas quanto os trotskistas peruanos tenham reprovado, em maior ou menor grau, o pensamento mariateguiano. Sua heresia não era apenas de postular uma revolução socialista para o Peru e a América Latina, mas conferi-la com um caráter original, sintetizada na consigna do socialismo indo-americano, tendo o indígena um papel central. Mariátegui, mesmo reconhecendo a debilidade do Estado nacional peruano, entendia que não se deveria buscar uma simples repetição mecânica e retardatária do percurso europeu, mas um esforço criativo e combinado, em uma síntese possível entre o local e o geral.

\section{Um brevíssimo epílogo da influência soviética na América Latina e o pensamento de Mariátegui}

A década de 1930 abriria o processo de stalinização dos partidos comunistas latinoamericanos. Após as prematuras mortes de Mella e Mariátegui, “iniciou-se um processo de degradação do pensamento marxista na América Latina que duraria várias décadas" (LÖWY, 1999, p.26). A imposição do modelo soviético, tanto em termos organizativos quanto doutrinários, para os partidos comunistas da América Latina foi um fator decisivo para a “degradação" que referia Löwy no pensamento marxista na região ${ }^{50}$. Se os primeiros lampejos que sucederam à Revolução Russa indicavam a possibilidade de um caminho promissor para o marxismo local, em paralelo e com maior incidência teríamos lideranças políticas diretamente afinadas com os pontos de vista político e intelectual do Komintern. Reproduziram na periferia as posições emanadas do centro hegemônico e manteriam com ela uma ligação estreita. Um significativo exemplo dessa categoria de marxistas seria o ítaloargentino Vittorio Codovilla (1894-1970), secretário-geral do PC argentino, que desde 1926

49 Exemplo dessa postura observa-se quando Trotsky, em 1936, comenta os riscos de uma iminente agressão militar fascista contra a URSS e condiciona o sucesso da resistência soviética a uma vitória dos socialistas ocidentais em seus países: "somente o proletariado europeu, irredutivelmente sublevado contra sua burguesia, poderá impedir a derrota da URSS" (TROTSKY, 1980, p.200).

50 Complementando tal ponto, "A lenda cruel sobre a mediocridade do marxismo cominternista dos anos vinte é resultado de um estranho casamento entre a história-tradição e a historiografia da guerra fria. Essa lenda pesou e segue pesando em excesso sobre a avaliação a respeito de Mariátegui. As reiteradas campanhas de 'bolchevização' de inspiração stalinista entre 1928 e 1930 tiveram um forte traço antiintelectualista, e em seus expurgos políticos evidenciaram a diversidade e complexidade de nossos marxismo e leninismo heterodoxos, sobre os quais Mariátegui se erigiu como figura símbolo" (MELGAR BAO, 2000, p.14).

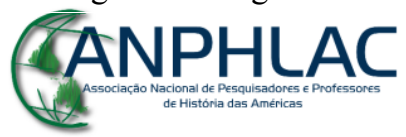

Revista Eletrônica da ANPHLAC, ISSN 1679-1061, №. 25, p. 87-115, Jul./Dez., 2018.

http://revista.anphlac.org.br 
era integrado às estruturas da Terceira Internacional. Suas posições eram inteiramente alinhadas à política central, acompanhando suas sutilezas e constantes viradas táticas. Durante o início do chamado Terceiro Período do Komintern, quando se adota uma linha de ofensividade contra a social-democracia (a doutrina stalinista a adjetivou como socialfascismo), Codovilla criaria o termo "nacional-fascismo" para enquadrar diversos governos latino-americanos, incluindo até ao governo de Lázaro Cárdenas ${ }^{51}$.

As sementes de um marxismo verdadeiramente latino-americano não mais germinariam com a mesma intensidade. As abordagens originais da geração de 1920 passariam a ser praticamente proscritas. O pensamento de Mariátegui, mais que colocado no ostracismo, seria abertamente condenado pela ortodoxia stalinista. No início da década de 1930, Eudocio Ravines, então secretário-geral do Partido Comunista do Peru (PCP), lançaria a consigna "desmariateguizar ao partido". Sintetizado no documento Bajo la bandera de Lenin, assinado pelo Comitê Central do PCP e publicado em fins 1933, determinava aos comunistas peruanos que "Nossa posição frente ao mariateguismo é e tem que ser de combate implacável e irreconciliável” (apud MANRIQUE, 2009, p.94). Em um primeiro momento, a direção comunista logrou êxito em sua campanha pelo apagamento dos traços do "mariateguismo" no partido e ao longo dos anos que se seguiram sua obra seria praticamente esquecida nos debates marxistas.

Tal conjuntura seria alterada apenas a partir da década de 1950 em um cenário geral de efervescência social que se anunciava quando um movimento revolucionário liderado por operários sacudiu a Bolívia e alguns anos depois, em 1959, a revolução cubana sagrara-se vitoriosa. A esquerda latino-americana passaria a buscar novamente trilhar seus próprios caminhos, amparada em grandes mobilizações sociais e com uma nova abertura intelectual. Não por acaso, será nesse mesmo período que o pensamento de Mariátegui será regatado, após os longos anos em que sua obra foi combatida pelo stalinismo. Em certa medida, a abertura revolucionária daquele momento levou muitos a procurarem fontes que vivenciaram a primeira revolução socialista do mundo sob um olhar latino-americano. Dessa perspectiva, Mariátegui era um interlocutor privilegiado, não apenas pelos seus relatos e vivências, mas principalmente por suas elaborações teóricas com traços de originalidade.

51 Cf. (CODOVILLA,1929, p.22).

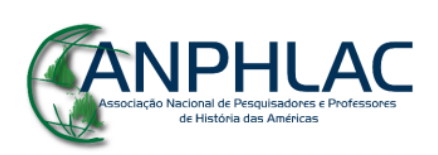

Revista Eletrônica da ANPHLAC, ISSN 1679-1061, №. 25, p. 87-115, Jul./Dez., 2018.

http://revista.anphlac.org.br 
O interesse pelas obras de Mariátegui seria cada vez maior ao longo das décadas de 1960 e 1970, ao ponto de nenhuma força política do espectro da esquerda, ou mesmo democrático-progressista, conseguir ficar indiferente ao pensamento mariateguiano no Peru. Sua copiosa e em grande parte esparsa produção teórica, aliada a importantes diferenças registráveis na evolução de seu pensamento, permitiram que vários e contrapostos intentos de utilização de seu legado fossem possibilitados a partir do uso parcial de matizes da obra mariateguiana para distintos interesses político-sociais ${ }^{52}$. Talvez a comparação que melhor ilustre os paradoxos do legado mariateguiano seja seu uso por figuras tão distintas, como a do general Juan Velasco Alvarado, ditador nacionalista que governou o Peru de 1968 a $1975^{53}$ e, em outro extremo, por Abimael Guzmán, líder da guerrilha peruana Sendero Luminoso ${ }^{54}$.

Possivelmente, se vivo, Mariátegui não aprovaria boa parte dos usos póstumos de sua obra, mas isto é apenas especulação, fato é que essa pluralidade de interpretações da obra de Mariátegui é indicativa de sua importância e atualidade. A postura intelectual de Mariátegui era antissectária, de constante busca por novas fontes e paradigmas que pudessem enriquecer suas elaborações. Afirmaria ele na Presentación de Amauta (1926) que: "Estudaremos todos os grandes movimentos de renovação políticos, filosóficos, artísticos, literários e científicos. Todo o humano é nosso." Será tal postura que permite ao intelectual peruano elaborar uma síntese latino-americana do marxismo. Diretamente influenciada pela Revolução Russa, não se restringirá aos exemplos políticos e aportes teóricos vindos de Moscou, mas fara uso de maneira combinada de outros elementos que lhe possibilita transcender limites analíticos até então colocados. Essa sua forma de conceber ao exercício do pensamento crítico - e do marxismo em particular - é um dos principais legados de Mariátegui. Como sintetizou Florestan Fernandes (1994, p.19), com apurada sensibilidade crítica ao projetar o futuro do marxismo, após o fim da URSS: "Patenteia-se, pois, o quanto Mariátegui transcendeu à órbita do marxismo triunfante do seu tempo e o quanto ele compartilha conosco na necessidade de ir mais longe ou perecer."

52 A coletânea organizada por José Aricó, Mariátegui y los origenes del marxismo latinoamericano (1978), traz algumas dessas abordagens, tais como o uso do legado de Mariátegui por tendências políticas opostas, como o Aprismo e o Stalinismo.

53 O "velasquismo", em seu apogeu, faria referência a Mariátegui a partir da inevitável citação do "nem decalque e nem cópia", para justificar a obra desse regime como uma opção revolucionária original, "nem capitalista nem comunista".

54 Guzmán batizou seu grupo armado a partir de uma frase de Mariátegui: "el marxismo-leninismo es el sendero luminoso del futuro".

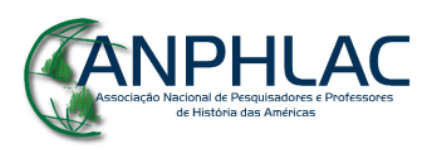

Revista Eletrônica da ANPHLAC, ISSN 1679-1061, №. 25, p. 87-115, Jul./Dez., 2018.

http://revista.anphlac.org.br 


\section{Referências:}

ARICÓ, José. Mariátegui y los origenes del marxismo latinoamericano. Cidade do México: Ediciones de Pasado y Presente/Siglo XXI, 1978. . Marx y América Latina. Buenos Aires: Fondo de Cultura Económica, 2009.

AMIN, Samir. El eurocentrismo: crítica de una ideologia. Cidade do México: Siglo XXI editores: 1989.

BIANCHI, Alvaro. O marxismo fora do lugar. Política \& Sociedade, v. 9, n. 16, p. 177-203, abr. 2010.

CLAUDIN, Fernando. A crise do movimento comunista. São Paulo: Expressão Popular, 2013.

CODOVILLA, Vittorio. La situación internacional de latino-américa y los peligros de guerra. IN: SECRETARIADO SUDAMERICANO DE LA I.C. El movimento revolucionário latinoamericano, versiones de la primera conferencia comunista latinoamericana. Buenos Aires, Correspondencia Sudamericana, 1929.

FERNANDES, Florestan. Significado atual de José Carlos Mariátegui. Revista Princípios, $\mathrm{n}^{\circ}$ 35, págs: 16-22. São Paulo: Editora Anita, nov/1994-jan/1995.

FLORES GALINDO, Alberto. La agonia de Mariátegui. La polémica con la Komintern. Lima: Desco, 1980.

FORNET-BETANCOURT, Raúl. O marxismo na América Latina. São Leopoldo: Editora Unisinos, 1995.

GORENDER, Jacob. Bolchevismo e internacionalismo. IN: COGGIOLA, Osvaldo. A revolução de outubro sob o olhar da história. São Paulo: Scritta, 1997.

GRAMSCI, Antonio. Escritos politicos. Cidade do México: Ediciones de Pasado y Presente, 1977.

JEIFETS, Lazar \& JEIFETS, Víctor. América Latina en la Internacional Comunista, 19191943. Diccionario Biográfico. Santiago: Ariadna Ediciones, 2015.

KOHAN, Néstor. Los combates de Mariátegui. IN: KOHAN, Néstor, LÖWY, M. \& PÉREZ, Gustavo. Mariátegui y la revolución em América Latina. Barcelona: Yulca editorial, 2014.

KONDER, Leandro. A derrota da dialética: a recepção das ideias de Marx no Brasil, até o começo dos anos 30. São Paulo: Expressão Popular, 2009.

p.47-48, 1998.

Chegada do Manifesto. Estudos Avançados. São Paulo: USP, Vol.12, nº 34,

\section{GANPHLAC}

Revista Eletrônica da ANPHLAC, ISSN 1679-1061, №. 25, p. 87-115, Jul./Dez., 2018.

http://revista.anphlac.org.br 
KOVAL, Boris. A grande revolução de outubro e a América Latina. São Paulo: Alfaomega 1980.

LANDER, Edgardo. Marxismo, eurocentrismo e colonialismo. In: BORON, Atilio A. (Org.) A teoria marxista hoje: problemas e perspectivas. Buenos Aires: CLACSO, 2007.

LENIN, V.I. Obras Escolhidas Tomo 2. Lisboa: Edições Avante!, 1984.

LÖWY, Michael. Introdução: pontos de referência para uma história do marxismo na América Latina. In: LÖWY, Michael (org.). O marxismo na América Latina: uma antologia de 1909 aos dias atuais. São Paulo: Fundação Perseu Abramo, 1999.

Introdução: nem decalque nem cópia: o marxismo romântico de José Carlos Mariátegui. In: MARIÁTEGUI, José Carlos. Por um socialismo indo-americano: ensaios escolhidos. Rio de Janeiro: UFRJ, 2005.

MANRIQUE, Nelson. ";Usted fue aprista!": Bases para una historia crítica del Apra. Lima: Fondo Editorial de la Pontificia Universidad Católica del Perú/CLACSO, 2009.

MARIÁTEGUI, José Carlos. Defesa do marxismo. São Paulo: Boitempo. 2011. .Ideologia y política. Lima: Editora Amauta, 1971.

. Figuras y aspectos de la vida mundial Vol. I. Lima: Editora Amauta, 1988.

Figuras y aspectos de la vida mundial Vol. III. Lima: Editora Amauta, 1986.

.La Escena Contemporánea. Lima: Editora Amauta, 1975.

Amauta, 2000.

Sete ensayos de interpretacion de la realidad peruana. Lima: Editora

Sete ensaios de interpretação da realidade peruana. São Paulo: CLACSO/Expressão Popular, 2008.

.Signos y obras. Lima: Editora Amauta, 1977.

MARTÍ, José. Obras Completas: Edición Crítica. Tomo 17. Havana: Centro de Estudios Martinianos, 2010.

MARX, Karl. \& ENGELS, Friedrich. El manifesto comunista. Madrid: Nordica Libros. 2012. .Materiales para la historia de América Latina. Córdoba: Ediciones Pasado y Presente, 1972.

MELGAR BAO, Ricardo. Mariátegui e a ocidentalização da política. Estudos de sociologia,

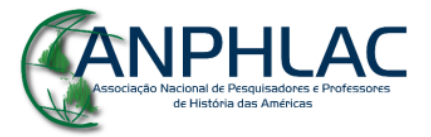

Revista Eletrônica da ANPHLAC, ISSN 1679-1061, №. 25, p. 87-115, Jul./Dez., 2018.

http://revista.anphlac.org.br 
Araraquara: UNESP, Vol. 5, $\mathrm{n}^{\circ}$ 9, 2000. p.01-24.

MELLA, Julio Antonio. Selección de textos: "como un leño en un incendio". Havana: Ruth Casa Editorial, 2008

MIROSHEVSKY, M. El "populismo" em el Perú. Papel de Mariátegui em la historia del pensamiento social latino-americano. IN: ARICÓ, José (Org.). Mariátegui y los origenes del marxismo latinoamericano. Cidade do México: Cuadernos de Pasado y Presente/Siglo XXI, 1978.

NETTO, José Paulo. Nota sobre o marxismo na América Latina. Novos Temas, Salvador/São Paulo, n.5/6, 2012, p.43-60.

PAREDES, Ricardo. Escritos Políticos. Quito: S/E, 2011.

PARIS, Robert. La formacion ideologica de José Carlos Mariátegui. Ciudad de Mexico: Ediciones Pasado y Presente, 1981.

PERICÁS, Luiz Bernardo. José Carlos Mariátegui e a Rússia. In: MARIATÉGUI, José Carlos. Revolução russa: história, política e literatura. São Paulo: Expressão Popular, 2012.

PORTANTIERO, Juan Carlos. Estudiantes y política en América Latina: el proceso de la reforma universitaria (1918-1938). Cidade do México: Siglo XXI, 1978.

QUIJANO, Anibal. Prólogo: José Carlos Mariátegui: Reencuentro y Debate In: MARIÁTEGUI, José Carlos. 7 ensayos de interpretación de la realidad peruana. Caracas: Fundación Biblioteca Ayacucho, 2007.

Treinta años después: otro reencuentro - notas para otro debate. In: MARIÁTEGUI, José Carlos. 7 ensayos de interpretación de la realidad peruana. Caracas: Fundación Biblioteca Ayacucho, 2007.

RAMA, Carlos M. El movimiento obrero y social en america latina: primeras experiences (1830-1917). Anuario de Estudios Centroamericanos. San José: Universidad de Costa Rica, 1980, Vol.6, p. 97-99.

SÁNCHEZ VÁSQUEZ, Adolfo. Mariátegui, grandeza e originalidade de um marxista latinoamericano. IN: PERICÁS, Luís Bernardo e BARSOTTI, Paulo (Org). América Latina: história, ideais e revolução. São Paulo: Xamã, 1998.

TROTSKY, Leon. A revolução permanente. Lisboa: Antídoto, 1977. A revolução traída. São Paulo: Global, 1980.

VANDEN, Harry. Mariátegui: influencias en su formación ideológica. Lima: Amauta, 1975.

\section{GANPHLAC}


ZORÍNA, A. A Grande Revolução Socialista de Outubro e os Países da América Latina. Fonte da $1^{\circ}$ edição: Problemas: Revista Mensal de Cultura Política $n^{\circ} 38$-Jan-Fev de 1952. Disponível em <https://www.marxists.org/portugues/tematica/rev_prob/38/revolucao.htm> Acesso em: 23 de junho de 2017.

\section{CANPHLAC}

